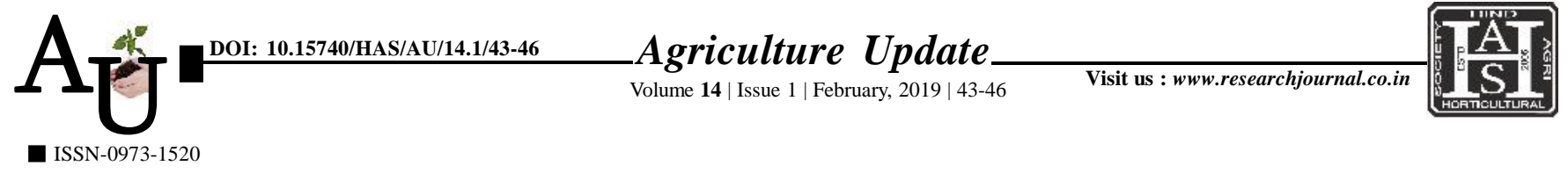

\title{
Research Article: Study on managerial efficiency of sericulturists regarding tasar silkworm rearing in Chhattisgarh
}

Kedar Nath Yadaw

Article Chronicle: Received :

11.09.2018;

Revised :

04.01.2019;

Accepted :

10.01.2019

KeY WordS:

Sericulturists, Tasar silkworm rearing, Managerial efficiency
Author for correspondence :

Kedar Nath Yadaw Krishi Vigyan Kendra, Dantewada (C.G.) India Email:yadawkn3886@ gmail.com
SUMMARY : The present study was conducted in 18 selected villages from the Raigarh and Korba districts of Chhattisgarh with 270 randomly selected sericulturists to assess the managerial efficiency of sericulturists regarding improved tasar silkworm rearing practices. The data were collected personally from sericulturists by using pre-tested and well structured interview schedule. The collected data were analyzed by using suitable statistical tools. As regards to overall level of managerial efficiency of sericulturists, 54.81 per cent of the sericulturists possessed high managerial efficiency. The overall managerial efficiency and managerial efficiency gap for different improved practices of sericulture production were observed to be 62.59 per cent and 37.41 per cent, respectively.

How to cite this article : Yadaw, Kedar Nath (2019). Study on managerial efficiency of sericulturists regarding tasar silkworm rearing in Chhattisgarh. Agric. Update, 14(1): 43-46; DOI : 10.15740/HAS/AU/14.1/43-46. Copyright@ 2019: Hind Agri-Horticultural Society. 